\title{
FIRST REPORT ON SEROEPIDEMIOLOGICAL AND CLINICAL INVESTIGATION OF CAT INFECTION WITH BARTONELLA HENSELAE IN THE AREA OF NOVI SAD, SERBIA
}

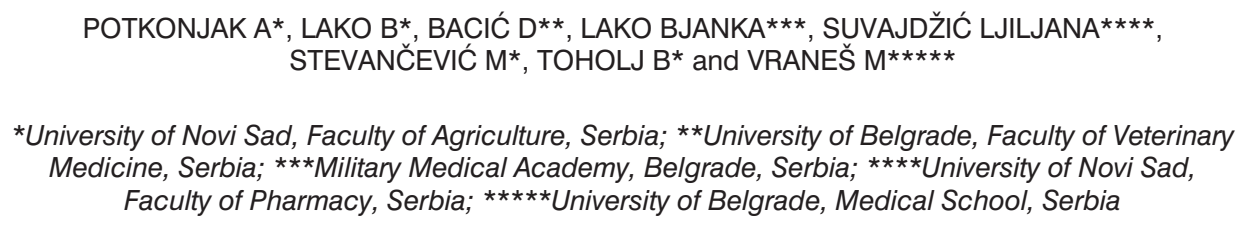

(Received 19th December 2010)

Cat Scratch Disease (CSD) is an infective disease of animals and humans caused with Bartonella henselae. Prevalence of infection varies between 0 and $68 \%$ depending on different population of cats and geographical region. Naturally infected cats are often clinically healthy and are inapparent germ carriers.

In this investigation 40 cats from the area of Novi Sad were analyzed. After the epidemiological questionnaire was made, all cats were clinically investigated. To determine the presence of specific antibodies of class $G$ on Bartonella henselae the method of indirect immunofluorescence was used.

For the first time in Serbia, in the area of Novi Sad municipality the infection caused by Bartonella henselae in the population of cats was detected. Prevalence of specific antibodies of class IgG on Bartonella henselae antigen in the population of cats was $57 \%$. The most common clinical manifestations in seropositive cats were gingivitis and lymphoadenopathy.

Key words: Bartonella henselae, cat infection, Cat Scratch Disease, IIF, immunodiagnostics, zoonoses

\section{INTRODUCTION}

Infection of cats with Bartonella henselae is determined as an infective disease of bacterial etiology, which is most often followed by an inapparent infection. According to the actual classification, the agent of the disease belongs to Genus of Bartonella and Family of Bartonellaceae. This Family incorporates more than 20 species and subspecies, out of which at least eight represent human pathogens (Boulouis et al., 2005). Cats could be infected except with Bartonella henselae also with Bartonella clarridgeiae, Bartonella coehlerae, Bartonella quintana i Bartonella bovis (Brunt et al., 2006).

Bartonella henselae was isolated for the first time from cats, during the eighties of the last century (Chomel et al., 2006a). Interestingly, presence of DNA 
from Bartonella henselae genotype Houston was detected in tooth pulp of a cat that lived about 800 years ago. This finding shows that even the agent of the disease was detected recently, the disease is not quite new (La et al., 2004). Domestic cat is main reservoir of Bartonella henselae, as well as of $B$. clarridgeiae $i$ $B$. koehlerae (Boulouis et al., 2005). Different types of wild cats also could be infected with Bartonellas (Chomel et al., 2006b). The role of vectors in spreading of different types of Bartonellas is not well known (Breitschwerdt and Kordick, 2000). Presence of cat fleas (Ctenocephalides felis) is necessary for the maintenance of infection in the cat population. Bartonella henselae reproduced in cat fleas (Finkelstein et al., 2002). Sero-epidemiolgical and bacteriological studies showed infection with Bartonella henselae in domestic cats worldwide (Boulouis et al., 2005). Infections of cats with Bartonellas were registered in different countries of Europe, Asia, Oceania and America (Brunt et al., 2006). Prevalence of infection varies depending of cat populations and geographical region. Values of prevalence of infection are lower in the regions with a cold climate ( $0 \%$ Norway), while in regions with hot and moisture climate are higher (68\% Philippines) (Chomel et al., 2006a). Prevalence of antibodies for Bartonella henselae antigens varies between 5 and $80 \%$, and prevalence to bacteria varies from few percents up to $50 \%$ of cat population (Boulouis et al., 2005).

Establishment of long intracellular bacteriemia in reservoir animals is an important process in the pathogenesis of infection with Bartonella henselae. Bartonellas are the only species among bacteria, capable to induce vasoproliferation, beside the known fact that there are some other bacteria that are linked to different tumors. Pathogenesis of vasoproliferation induced by Bartonella henselae is complex and includes several biological mechanisms. There are different factors of Bartonella henselae virulence that are important in the infection process. The most important are: low toxic LPS, non-fibrial adhesins (BadA, VompA-D) and Bartonell translocated proteins (BepA-BepG) (Dehio, 2005). Expression of mRNA for IL-4, but no INF- $\gamma$ was observed in infected cats during bacteriemia, which implicates the activation of Th2 immune response (Kabeya et al., 2006). It was also observed that in cats infected with Bartonella henselae LSU 16, antibodies of class IgM are detectable three weeks upon infection and that amount of antibodies decreases six weeks upon infection. Maternal antibodies specific for Bartonella henselae are transmitted via colostrum on newborns and persist during 10 weeks (Guptill et al., 1998). In some cats infected with Bartonella henselae during bacteriemia. A high titer of circulating antibodies was detected. Therefore, the role of humoral immune response in this type of infection is not clear (Freeland et al., 1999). It is reported that the number of bacteria decreases with the concentration of IgG antibodies against Bartonella henselae. This humoral immune response significantly improves bactericidal activity. It is considered that antibodies have a certain role in the elimination of Bartonellas, but not enough to eliminate them completely (Kabeya et al., 2006).

Because of high prevalence on infection of cats with Bartonella henselae it is quite difficult to link specific clinical symptoms with infection. Cats which are infected experimentally with Bartonella henselae show different symptoms like: fever that persist from two days up to few weeks, local inflammation, 
Acta Veterinaria (Beograd), Vol. 61, No. 2-3, 183-192, 2011.

lymphoadenopathy, lethargy, anorexia, reproductive disorders and neurological problems (Chomel et al., 2004). Also anemia could be present (Breitschwerdt and Kordick, 2000). Naturally infected cats are often clinically healthy and inapparent germ carriers. Seropositive cats often have: lymphadenitis, gingivitis, stomatitis, as well as urological problems (Chomel et al., 2003a). It is believed that Bartonella henselae is a potential cause of endocarditis in cats (Chomel et al., 2003b). A link between infection with Bartonellas and uveitis was observed (Ketring et al., 2004). Persistent infection with Bartonellas does not lead to a lethal outcome in chronically infected cats. Clinical symptoms are minimal or not present in persistent infection. Cats infected with Bartonella henselae or Bartonella quintana do not show pathomorphological changes. Pathohystological changes include peripheral hyperplasia of lymph nodes, follicular hyperplasia of spleen, lymphocytic holangitis/periholangitis, lymphocytic hepatitis, lymphoplasmocytc miocarditis and intersticial lymphocytic nephritis (Kordick et al., 1999). Coinfection with other species and strains of Bartonellas is possible, as well as with other agents of infective disease. A significant correlation between cats seropositive on Bartonella henselae and Borrelia burgdorferi was described (Shaw et al., 2001). Cats infected with Bartonella henselae and Feline immunodeficiency virus (FIV), show increased incidence of lymphoadepoathy and gingivitis, which is explained by immunocompromisation due to CD4+ lymphocyte depletion (Breitschwerdt and Kordick, 2000; Shaw et al., 2001).

Diagnostics based on clinical symptoms is quite difficult due to the fact that many clinically healthy cats are chronically infected (Chomel et al., 2004). Laboratory diagnostics of infection with Bartonella henselae include direct and indirect methods. In other words detection of agents from clinical samples and detection of specific antibodies (Rode, 2005). There are many serological detection tests designed for cats. IFA, test use whole bacteria of Bartonella henselae as antigen, while others including ELISA use specific single antigens (Brunt et al., 2006). Commercial IFA tests, most often use Vero cell line infected with Bartonella henselae (Zbinden et al., 1997). ELISA is still not in use since there is no ideal antigen for this purpose (Rode, 2005). Conducting serological tests is fast and cheap. Negative results of serological tests do not exclude disease, and furthermore there is intercross reaction within Genus Bartonella (Brunt et al., 2006). Intercross reactivity could also be observed with Chlamidia and Coxiella burnetii (La Scola and Raoult, 1996; Maurin et al., 1997b). To diagnose human infection with Bartonella henselae IFA is standard test (Chomel et al., 2004). There is no study describing specificity and sensitivity of serological tests used for diagnostics of infections with Bartonellas in cats. It is reported that IFA test for presence of IgG antibodies for Bartonella henselae is 99\% sensitive and 94\% specific (Boulouis et al., 2005).

\section{MATHERIALS AND METHODS}

Blood serums from 40 cats from the region of Novi Sad were obtained. Blood sampling was done in veterinarian ambulances and other institutions involved in veterinarian medicine. Each blood sample was followed with an 
epidemiological questionnaire and clinical examination of cats. To determine the presence of specific antibodies of class $\mathrm{G}$ on Bartonella henselae antigens test of indirect imunofluorescence (IIF) was used (manufacturer: VMRD, USA). Test of IIF was made according to manufacturer's instructions. Titer of specific antibodies higher than 1:50 was recognaized as positive. Fluorescence intensity of intracellular bacteria ranged between $1+$ and $4+$.

\section{RESULTS}

\section{Epidemiological questionnaire}

Out of the total number of 27 samples $(67 \%)$, were collected in veterinary ambulances and other institutions from the field of veterinarian medicine. The samples were collected from cats that were brought for clinical examination, treatment or blood sampling, while 13 samples $(33 \%)$ were obtained from healthy cats. In Novi Sad 21 samples were collected (52\%), while 7 samples were obtained from adjacent city zones (18\%). Data about collection area of samples are not known for 12 (30\%) samples. Out of the total number of blood samples, 4 samples (10\%) originated from cats that are one year old, $26(65 \%)$ samples are from cats older than one year, while 10 samples $(25 \%)$ originate from cats for which data are unknown. Males represent 19 (47\%) of analyzed cats, females 11 (28\%), while data representing the sex of the cats are unknown for 10 samples (25\%). Population of analysed cats represents 29 (72\%) cats with short hair, $1(3 \%)$ cat with long hair, and $10(25 \%)$ cats for which data are not known. Beside this epidemiological feature we followed the life style of cats. Out of the total number, 12 cats $(30 \%)$ live in houses together with their owners, while 18 cats $(45 \%)$ live outdoors. This data are not known for $10(25 \%)$ cats. Predation was a feature of 21 $(52 \%)$ cats, while 7 of them were not predators (18\%). This data are not known for $12(30 \%)$ cats. Out of the total number $16(39 \%)$ cats were bitten by fleas, while 13 $(33 \%)$ was not bitten, and data are not known for $11(28 \%)$ cats. It was found that $28(70 \%)$ cats out of total number were infested by ticks, while this data are not known for $12(30 \%)$ cats.

\section{Clinical examination}

Out of 40 cats included in the study, 30 cats $(75 \%)$ were clinically examined, while $25 \%$ were not available. Clinical examination revealed signs and symptoms of disease in $23(77 \%)$ of examined cats, while 7 cats $(23 \%)$ had no pathological changes. Clinical examination conducted in accordance with the literature data regarding the symptoms of Bartonella henselae infection revealed gingivitis as the most frequent change (28\%) in tested cats. Lymphoadenopathy $(22 \%)$ and urological disorders (8\%) were also observed. Sporadically, we observed anorexia $(6 \%)$, lethargy $(6 \%)$, local skin inflammation $(6 \%)$, skin erythema $(6 \%)$, stomatitis $(6 \%)$, skin edema (3\%), hepatitis $(3 \%)$, vestibular dysfunction (3\%) and ophtamological changes (3\%) (Graph 1). Hematological exam of one cat with observed lymphoadenopathy showed leucocytosis $\left(11 \times 10^{9} / \mathrm{L}\right)$. Body temperature, hart beating and respiration frequency were at physiological range for the species. Clinical exam of cats included in the study did not reveal 
Acta Veterinaria (Beograd), Vol. 61, No. 2-3, 183-192, 2011.

Potkonjak A et al.: First report on seroepidemiological and clinical investigation

of cat infection with Bartonella henselae in the area of Novi Sad, Serbia

endocarditis, miocarditis, nefritis, attitude alterations or reproductive disorders. Some of observed changes such are phlegmona, otitis externa, conjunctivitis, granulomatous skin proliferation, bronchitis, uterus torsion, opstipation, and skin neoplasia were probably not related to Bartonella henselae infection.

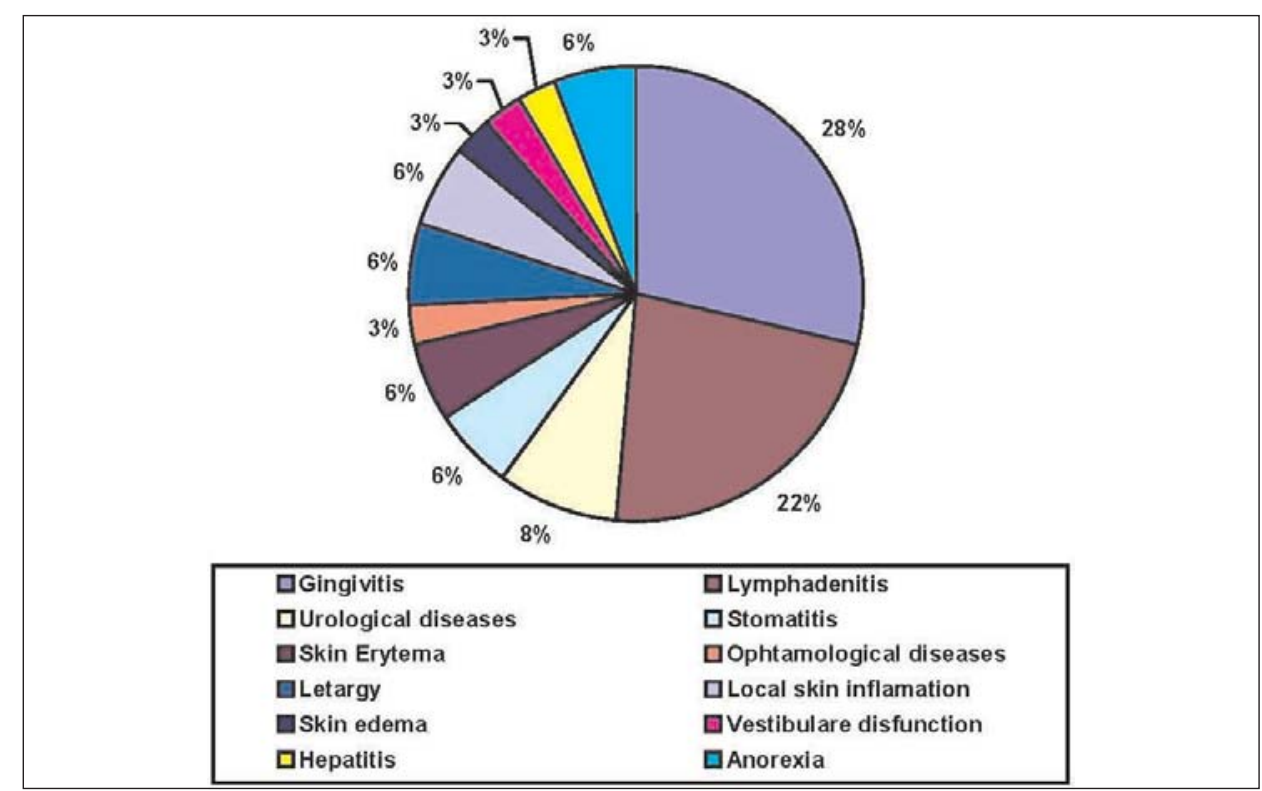

Graph 1. Results of clinical examination

Results of indirect immunofluorescence assay for Bartonella henselae specific IgG antibodies

Out of 40 serologically examined cats, 17 (43\%) were negative on presence of specific antibodies for Bartonella henselae (Graph 2). We determined the presence of specific antibodies for Bartonella henselae in $23(57 \%)$ blood samples (Graph 2, Fig 1). Antibodies at 1:50 titer were present in 7 sera, 1:100 in 7 sera, 1:200 in 1 serum, 1:400 in 6 sera and 1:800 in 2 sera. Average fluorescence intensity at 1:50 dilution was 3+ arbitrary scale and was detected in 10 sera. The

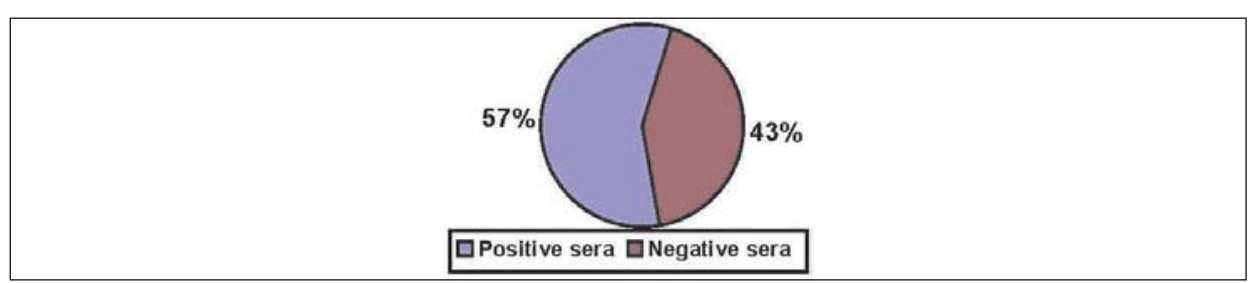

Graph 2. Results of IIF assay for presence of IgG antibodies against Bartonella henselae 
majority of cats with a detected presence of specific IgG antibodies against Baronella henselae were males, older than one year, short hair, which live outdoor, with reported predator behavior. The presence of specific antibodies correlated with clinical symptoms of Bartonella henselae infection.

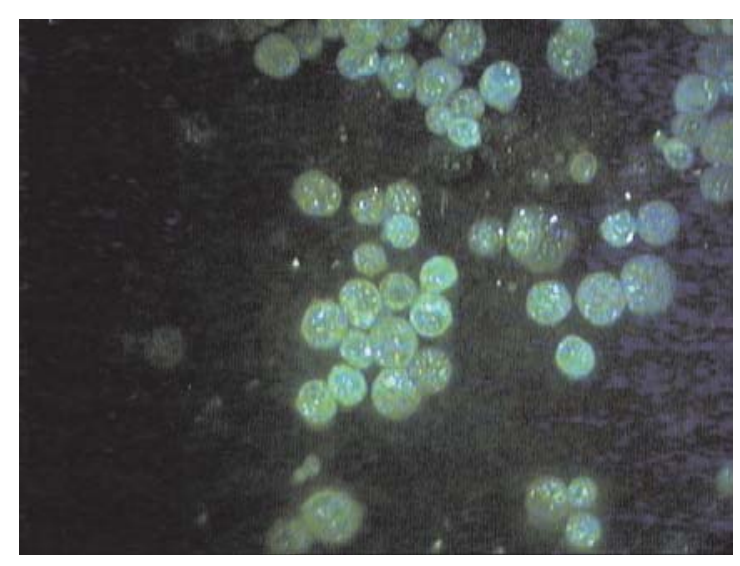

Fig 1. Indirect immunofluorescence, $x 400$, fluorescence intensity $4+$, titer dilution for IgG specific antibodies against Bartonella henselae 1:50

\section{DISCUSSION}

Bartonellas are slow growing, hemotropic, gram negative agents of infective diseases of humans and domestic and wild animals. Infection is persistent and vector borne. Cat scratch disease was described in humans during the fifties of the last century and represents a classical zoonose. Medical importance of this disease is increasing. Cats represent an important reservoir of Bartonella henselae. Humans are infected incidentally due to contact with cats, by scratch or by bite (Chomel et al., 2004).

There is no report on the presence and distribution of infection of cats with Bartonella henselae. Different factors that lead to infection and distribution of the disease are responsible for the presence of this illness in humans and cats. We investigated the presence of the antigen in the area of Novi Sad. Samples were collected randomly in veterinary ambulances and other institutions of veterinary medicine.

In this study we observed that the group of seropositive cats is dominated by males. Breitschwerdt and associates also demonstrated domination of seropositive males (Breitschwerdt et al., 2005). Maruyama and associates (1988 and 2003) presented similar results. This fact could be explained by the life style of males during estrus of females.

During this period males often cause skin scratches that lead to Bartonella henselae infection (Maruyama et al., 1998). Al-Majali did not observe a connection between sex and seropositivity on Bartonella henselae (Al-Majali, 2004). Glaus 
Acta Veterinaria (Beograd), Vol. 61, No. 2-3, 183-192, 2011.

also described the absence of a correlation between sex and seropositivity on Bartonella henselae (Glaus et al., 1997). We determined that seropositive cats are dominantly older than one year. This was also observed by Glaus and Guptill (Glaus et al., 1997; Guptill et al., 2004). Although, most studies show that seroprevalence on Bartonella henselae is higher in the population of cats younger than one year (Childs et al., 1994; Chomel et al., 1995; Koehler et al., 1994; Maruyama et al., 2003). Neither Maruyama and associates nor Breitschwerdt had shown the correlation between Bartonella henselae seropositivity and cat age (Breitschwerdt et al., 2005; Maruyama et al., 1998). As in this study blood was largely sampled from short haired cats, we cannot drow a conclusion regarding hair length as a risk factor for Bartonella henselae infection. Al-Majali determined outdoor life and predator behavior as risk factors for Bartonella henselae (AlMajali, 2004). A similar observation was reported by Breitschwerdt (Breitschwerdt et al., 2005). The result of this study is in line with these findings. Rolain et al. (2004a) observed less frequent seropositivity for Bartonella henselae antibodies in cats living in house exclusively. It is considered that outdoor cats with predator behavior are more exposed to contact with fleas and other sources of infection. Yet, Guptill did not observe a correlation between cat habitat and Bartonella henselae seropositivity (Guptill et al., 2004). High Bartonella henselae seroprevalence levels in cats in the moist and warm climate is explained with optimal conditions for arthropod vectors proliferation such are cat fleas. Maruyama et al. (2003) point to the correlation between infestment of cats with fleas and Bartonella henselae seropositivity. Al-Majali (2004) also reported an increased percent of seropositivity among flea-infested cats. Similar results were described by Guptill (Guptill et al., 2004). We did not observe a clear correlation between the presence of fleas and ticks and Bartonella henselae seropositivity, probably because the study was conducted during the cold months when infestation of cats with ectoparasites is reduced (Gurfield et al., 2001).

This study revealed impaired health status of Bartonella henselae seropositive cats. Two conditions with the highest frequency were gingivitis and lymphoadenophaty. This could be explained either by higher susceptibility of Bartonella henselae infected cats for other diseases or by the inability of infected cats to fight Bartonella henselae infection. There is also a possibility that clinically observed gingivitis is a consequence of coinfection with other agents of cat infectious disease such as feline syncytial virus (FeSFV). Glaus observed a significant presence of gingivitis and urological diseases in the group of seropositive cats with Bartonella henselae (Glaus et al., 1997). Studies made in Switzerland (country with relatively low seroprevalence for Bartonella henslae) show that lymphoadenopathy is in correlation with the presence of antibodies against Bartonella henselae. Studies made in Japan showed correlation between seroprevalnce for Bartonella henselae and presence of gingivitis and lymphoadenopathy. The same type of correlation was observed in North America. Breitschwerdt et al. (2005) did not observe a correlation between seroprevalence and development of gingivitis and lymphadenopathy.

We observed a prevalence of IgG antibodies against Bartonella henselae of $57 \%$ on the territory of Novi Sad municipality. It is already reported that 
seroprevalence for antibodyes against Bartonella henselae varies between 5 and $80 \%$ (Boulouis et al., 2005). According to reports from France the percent of seroprevalent cats is $41 \%$ (Gurfield et al., 2001). Seroprevalence in cats in the Netherlands is about $56 \%$. (Bergmans et al., 1997). Seroprevalence was reported in $33 \%$ of cats in Austria (Boulouis et al., 2005). Seroprevalence in Denmark is $45.6 \%$ (Chomel et al., 2002). Very low percentage of seroprevalnce was detected in Sweden,1\% (Hjelm et al., 2002), as wll as 2.2\% (Engvall et al., 2003). In Switzerland seroprevalence was detected in $8.3 \%$ of cats (Glaus et al., 1997). In Great Britain seroprevalence was observed in $41.8 \%$ (Barnes et al., 2000). In Italy this percent is $38 \%$ (Fabbi et al., 2004). In Portugal, seroprevalence was detected in $6.7 \%$ cases (Boulouis et al., 2005). All presented data on seroprevalence of antibodies against Bartonella henselae in the population of cats shows correspondence with our result obtained for Novi Sad.

In our investigation we reported infection of cats with Bartonella henselae using specific IgG antibodies. This suggests a need for further development of optimal diagnostic procedures exploiting techniques such as PCR, ELISA and Western blotting.

Address for correspondence:

Lako Branislav MD PhD, Associate Professor

Trg Dositeja Obradovića 8

21000 Novi Sad, Serbia

E-mail: blako@polj.ns.ac.yu

\section{REFERENCES}

1. Al-Majali AM, 2004, Seroprevalence of and risk factors for Bartonella henselae and Bartonella quintana infections among pet cats in Jordan, Prev Vet Med, 64, 63-71.

2. Barnes A, Bell SC, Isherwood DR, Bennett M, Carter SD, 2000, Evidence of Bartonella henselae infection in cats and dogs in the United Kingdom, Vet Rec, 147, 673-7.

3. Bergmans AM, de Jong CM, van Amerongen G, Schot CS, Schouls LM, 1997, Prevalence of Bartonella species in domestic cats in The Netherlands, J Clin Microbiol, 35, 2256-61.

4. Boulouis HJ, Chang CC, Henn JB, Kasten RW, Chomel BB, 2005. Factors associated with the rapid emergence of zoonotic Bartonella infections, Vet Res, 36, 383-410.

5. Breitschwerdt EB, Kordick DL, 2000, Bartonella infection in animals: carriership, reservoir potential, pathogenicity, and zoonotic potential for human infection, Clin Microbiol Rev, 13, 428-38.

6. Breitschwerdt EB, Levine JF, Radulovic S, Hanby SB, Kordick DL, La Perle KMD, 2005, Bartonella henselae and Rickettsia Seroreactivity in a Sick Cat Population from North Carolina, Intern J Appl Res Vet Med, 3, 287-302.

7. Brunt J, Guptill L, Kordick DL, Kudrak S, Lappin MR, P. American Association of Feline, P. Academy of Feline Medicine Advisory, 2006, American Association of Feline Practitioners 2006 Panel report on diagnosis, treatment, and prevention of Bartonella spp. infections, J Feline Med Surg, 8, 213-26.

8. Childs JE, Rooney JA, Cooper JL, Olson JG, Regnery RL, 1994. Epidemiologic observations on infection with Rochalimaea species among cats living in Baltimore, Md, J Am Vet Med Assoc, $204,1775-8$.

9. Chomel BB, Boulouis HJ, Breitschwerdt EB, 2004, Cat scratch disease and other zoonotic Bartonella infections, J Am Vet Med Assoc, 224, 1270-9.

10. Chomel BB, Boulouis HJ, Maruyama S, Breitschwerdt EB, 2006a, Bartonella spp. in pets and effect on human health, Emerg Infect Dis, 12, 389-94. 
Acta Veterinaria (Beograd), Vol. 61, No. 2-3, 183-192, 2011

11. Chomel BB, Kasten RW, Henn JB, Molia S, 2006b, Bartonella infection in domestic cats and wild felids, Ann NY Acad Sci, 1078, 410-5.

12. Chomel BB, Kasten RW, Sykes JE, Boulouis HJ, Breitschwerdt EB, 2003a, Clinical impact of persistent Bartonella bacteremia in humans and animals, Ann NY Acad Sci, 990, 267-78.

13. Chomel BB, Wey AC, Kasten RW, Stacy BA, Labelle P, 2003b, Fatal case of endocarditis associated with Bartonella henselae type I infection in a domestic cat, J Clin Microbiol, 41, 5337-9.

14. Chomel BB, Abbott RC, Kasten RW, Floyd-Hawkins KA, Kass PH, Glaser CA et al., 1995, Bartonella henselae prevalence in domestic cats in California: risk factors and association between bacteremia and antibody titers, J Clin Microbiol, 33, 2445-50.

15. Chomel BB, Boulouis HJ, Petersen H, Kasten RW, Yamamoto K, Chang CC et al., 2002, Prevalence of Bartonella infection in domestic cats in Denmark, Vet Res, 33, 205-13.

16. Dehio C, 2005. Bartonella-host-cell interactions and vascular tumour formation, Nat Rev Microbiol, $3,621-31$.

17. Engvall EO, Brandstrom B, Fermer C, Blomqvist G, Englund L, 2003, Prevalence of Bartonella henselae in young, healthy cats in Sweden, Vet Rec, 152, 366-9.

18. Fabbi M, De Giuli L, Tranquillo M, Bragoni R, Casiraghi M, Genchi C, 2004, Prevalence of Bartonella henselae in Italian stray cats: evaluation of serology to assess the risk of transmission of Bartonella to humans, J Clin Microbiol, 42, 264-8.

19. Finkelstein JL, Brown TP, O'Reilly KL, Wedincamp J Jr, Foil LD, 2002. Studies on the growth of Bartonella henselae in the cat flea (Siphonaptera: Pulicidae), J Med Entomol, 39, 915-9.

20. Freeland RL, Scholl DT, Rohde KR, Shelton LJ, O'Reilly KL, 1999, Identification of Bartonellaspecific immunodominant antigens recognized by the feline humoral immune system, Clin Diagn Lab Immunol, 6, 558-66.

21. Glaus T, Hofmann-Lehmann R, Greene C, Glaus B, Wolfensberger C, Lutz H, 1997, Seroprevalence of Bartonella henselae infection and correlation with disease status in cats in Switzerland, J Clin Microbiol, 35, 2883-5.

22. Guptill L, Slater LN, Wu CC, Lin TL, Glickman LT, Welch DF et al., 1998. Evidence of reproductive failure and lack of perinatal transmission of Bartonella henselae in experimentally infected cats, Vet Immunol Immunopathol, 65, 177-89.

23. Guptill L, Wu CC, HogenEsch H, Slater LN, Glickman N, Dunham A et al., 2004, Prevalence, risk factors, and genetic diversity of Bartonella henselae infections in pet cats in four regions of the United States, J Clin Microbiol, 42, 652-9.

24. Gurfield AN, Boulouis HJ, Chomel BB, Kasten RW, Heller R, Bouillin C et al., 2001, Epidemiology of Bartonella infection in domestic cats in France, Vet Microbiol, 80, 185-98.

25. Hjelm E, McGill S, Blomqvist G, 2002. Prevalence of antibodies to Bartonella henselae, $B$. elizabethae and B. quintana in Swedish domestic cats, Scand J Infect Dis, 34, 192-6.

26. Kabeya H, Sase M, Yamashita M, Maruyama S, 2006, Predominant T helper 2 immune responses against Bartonella henselae in naturally infected cats, Microbiol Immunol, 50, 171-8.

27. Ketring KL, Zuckerman EE, Hardy WD Jr, 2004, Bartonella: a new etiological agent of feline ocular disease, J Am Anim Hosp Assoc, 40, 6-12.

28. Koehler JE, Glaser CA, Tappero JW, 1994, Rochalimaea henselae infection. A new zoonosis with the domestic cat as reservoir, Jama, 271, 531-5.

29. Kordick DL, Papich MG, Breitschwerdt EB, 1997, Efficacy of enrofloxacin or doxycycline for treatment of Bartonella henselae or Bartonella clarridgeiae infection in cats, Antimicrob Agents Chemother, 41, 2448-55.

30. La Scola B, Raoult D, 1996, Serological cross-reactions between Bartonella quintana, Bartonella henselae, and Coxiella burnetii, J Clin Microbiol 34:2270-4.

31. La VD, Clavel B, Lepetz S, Aboudharam G, Raoult D, Drancourt M, 2004, Molecular detection of Bartonella henselae DNA in the dental pulp of 800-year-old French cats, Clin Infect Dis, 39 , 1391-4.

32. Maruyama S, Kabeya H, Nakao R, Tanaka S, Sakai T, Xuan X et al., 2003, Seroprevalence of Bartonella henselae, Toxoplasma gondii, FIV and FeLV infections in domestic cats in Japan, Microbiol Immunol, 47, 147-53. 
33. Maruyama S, Hiraga S, Yokoyama E, Naoi M, Tsuruoka Y, Ogura Y et al., 1998, Seroprevalence of Bartonella henselae and Toxoplasma gondii infections among pet cats in Kanagawa and Saitama Prefectures, J Vet Med Sci, 60, 997-1000.

34. Maurin M, Eb F, Etienne J, Raoult D, 1997b. Serological cross-reactions between Bartonella and Chlamydia species: implications for diagnosis, J Clin Microbiol, 35, 2283-7.

35. O'Reilly KL, Bauer RW, Freeland RL, Foil LD, Hughes KJ, Rohde KR et al., 1999, Acute clinical disease in cats following infection with a pathogenic strain of Bartonella henselae (LSU16), Infect Immun, 67, 3066-72.

36. Rode $Đ O, 2005$, Dijagnostika toksoplazmoze i bartoneloze, Paediatr Croat, 41, 212-8.

37. Rolain JM, Locatelli C, Chabanne L, Davoust B, Raoult D, 2004a, Prevalence of Bartonella clarridgeiae and Bartonella henselae in domestic cats from France and detection of the organisms in erythrocytes by immunofluorescence, Clin Diagn Lab Immunol, 11, 423-5.

38. Shaw SE, Birtles RJ, Day MJ, 2001, Arthropod-transmitted infectious diseases of cats, J Feline Med Surg, 3, 193-209.

39. Zbinden R, Michael N, Sekulovski M, von Graevenitz A, Nadal D, 1997, Evaluation of commercial slides for detection of immunoglobulin $G$ against Bartonella henselae by indirect immunofluorescence, Eur J Clin Microbiol Infect Dis, 16, 648-52.

\title{
PRVI IZVEŠTAJ O RASPROSTRANJENOSTI I KLINIČKOJ SLICI INFEKCIJE MAČAKA SA BARTONELLA HENSELAE NA PODRUČJU NOVOG SADA
}

\author{
POTKONJAK A, LAKO B, BACIĆ D, LAKO BJANKA, SUVAJDŽIĆ LJILJANA, \\ STEVANČEVIĆ M, TOHOLJ B i VRANEŠ M
}

\section{SADRŽAJ}

Bolest mačijeg ogreba (BMO) je infektivno oboljenje životinja i ljudi izazvano sa Bartonella henselae. Prevalencija infekcije varira u zavisnosti od populacije mačaka i geografskog regiona i kreće se od 0 do $68 \%$. Prirodno inficirane mačke su često klinički zdrave, inaparentne kliconoše.

$\mathrm{U}$ istraživanje je bilo uključeno 40 mačaka sa područja Novog Sada. Nakon uzimanja epidemiološke ankete, sve mačke su klinički pregledane. Za utvrđivanje prisustva specifičnih antitela klase $\mathrm{G}$ na antigene Bartonella henselae korišćen je test indirektne imunofluorescencije.

Na geografskom području grada Novog Sada i okoline, po prvi put je u Republici Srbiji, utvrđeno prisustvo infekcije izazvane uzročnikom Bartonella henselae u populaciji mačaka. Prevalencija specifičnih antitela klase lgG na antigen Bartonella henselae u populaciji mačaka iznosila je $57 \%$. Najčešće kliničke manifestacije kod seropozitivnih mačaka bile su gingivitis i limfadenopatija. 